\title{
РОЗВИТОК ТВОРЧОГО ПОТЕНЦІАЛУ МАЙБУТНЬОГО ВИКЛАДАЧА ХОРЕОГРАФГЧНИХ ДИСЦИПЛІН
}

\author{
Бунчук О. В.
}

кандидат педагогічних наук, старший викладач кафедри педагогіки та педагогічної майстерності, Мелітопольський державний педагогічний університет імені Богдана Хмельницького,м. Мелітополь, Україна

\section{Коропаткова А. К.}

здобувач другого (магістерського) рівня вищої освіти кафедри педагогіки та педагогічної майстерності, Мелітопольський державний педагогічний університет імені Богдана Хмельницького, м. Мелітополь, Україна

У публікаиії представлено аналіз розвитку творчого потенціалу майбутнього викладача хореографічних дисииплін. 3'ясовано, що підготовка майбутнього викладача хореографічних дисциплін має багатовекторний характер, щзо полягає у складному поєднанні професійнопедагогічної та фахово-хореографічної складових.

Ключова слова: професійна підготовка, хореографічні дисиипліни, творчий потенціал, майбутній викладач хореографії.

The publication analyzes the development of the creative potential of the future teacher of choreographic disciplines, which revealed that the training of future teachers of choreographic disciplines has a multi-vector nature, which is a complex combination of professional and pedagogical and professional choreographic components.

Key words: professional training, choreographic disciplines, creative potential, future teacher of choreography.

Сучасний етап розвитку хореографічної освіти актуалізує питання підготовки педагога-хореографа нового типу, що відображає суспільний попит на вмотивованого на педагогічну професію викладача-професіонала, який не лише володіє необхідними фаховими й педагогічними компетентностями, а й виявляє розвинений професійний інтерес до навчання здобувачів основам хореографічного мистецтва, має сформовану педагогічну позицію щодо творчого виховання молоді.

Розвиток творчих здібностей здобувачів привертав увагу багатьох вчених, які розглядали такі питання: суть поняття розвиток творчих здібностей (Б. Ананьєв, В. Андреєв, Д. Богоявленська, 
Н. Кузьміна, М. Лазарев, В. Моляко, М. Поташник, Н. Посталюк, Е. Яковлєва), зміст і шляхи підготовки вчителя до творчої професійної діяльності (Ю. Азаров, І. Зязюн, О. Піскулов, Н. Кичук та ін.), формування творчого потенціалу майбутнього педагога в процесі вивчення мистецьких дисциплін (В. Воєводін, Г. Гладишев, В. Орлов, В. Лихвар), напрями розвитку творчої особистості вчителів хореографії (Л. Андрощук, О. Білаш, І. Герц, У. Козубаш, О. Отич, І. Поклад, О. Попик, С. Роботько, І. Спінул, І. Тригуб, С. Тригуб, П. Фриз та ін.).

Одним з найважливіших напрямів розвитку творчого потенціалу майбутніх викладачів хореографічних дисциплін є створення умов, які сприяють формуванню їх творчих здібностей (Л. Андрощук, У. Вінницька, Б. Компан та ін.).

На думку С. Куценко, є три типи творчих завдань, які впливають на формування творчого потенціалу майбутнього викладача хореографічних дисциплін: перший тип - творчі завдання з елементами гри та змагання; другий тип - творчі завдання, в яких створюється ситуація можливого вибору певної дії; третій тип - творчі завдання на основі імпровізації [1, с. 157].

На основі аналізу дослідженої проблеми вчені виділили чотири основні умови успішного розвитку творчих здібностей майбутніх викладачів хореографічних дисциплін, які доцільно застосовувати під час викладання сучасних напрямів хореографічного мистецтва:

- творча взаємодія викладача і студента;

- демократичний характер педагогічного процесу;

- застосування інтерактивних технологій навчання;

- наявність креативного стилю діяльності викладача [2, с.12].

Для формування креативності, як відомо, потрібно спеціально організоване середовище (творчі лабораторії, навчально-методичні комплекси із завданнями на розвиток творчої індивідуальності студентів). Крім того, важливо стимулювати пошук індивідуального стилю, підтримувати бажання здобувача до застосування інновацій у хореографічному мистецтві, відходити від загальноприйнятих канонів у хореографії, активізувати пошук власного стилю [1, с.164].

Отже, узагальнюючи вищесказане, можна зробити висновок, що розвиток творчого потенціалу майбутнього викладача хореографічних 
Розділ II. Особистісні та соціальні детермінанти духовно-інтелектуального

виховання і навчання в системі неперервної освіти

дисциплін можливий за таких умов як творча суб'єкт-суб' єктна взаємодія, демократичний характер освітнього процесу, застосування інтерактивних технологій навчання, наявність неординарного стилю діяльності викладача.

\section{Список використаних джерел:}

1. Розвиток художньо-естетичного світогляду майбутніх вчителів хореографії на основі інтегративного підходу: колективна монографія / за заг. ред. О. В. Мартиненко. Бердянськ : Видавець Ткачук О.В., 2015. С. 155-166.

2. Рудницька О. П. Педагогіка: загальна та мистецька: навч. посіб. Тернопіль : Навчальна книга Богдан, 2005. 360 с. 